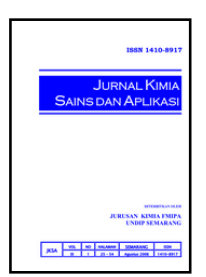

\title{
Studi Kemampuan Adsorpsi Zeolit Alam Terdealuminasi terhadap Senyawa Fenol dan 2-Metoksifenol pada Asap Cair Sekam Padi: Eksperimen dan Komputasi AB Initio
}

\author{
Wempie Gressangga $^{\mathrm{a}}$, Suhartana ${ }^{\mathrm{b}}$, Parsaoran Siahaan ${ }^{\mathrm{a}^{*}}$ \\ a Inorganic Chemistry Laboratory, Chemistry Department, Faculty of Sciences and Mathematics, Diponegoro University, Jalan Prof. \\ Soedarto, Tembalang, Semarang \\ * Corresponding author: siahaan.parsaoran@live.undip.ac.id
}

\begin{tabular}{|c|c|}
\hline Article Info & Abstract \\
\hline & Study of dealuminated natural zeolite ability to adsorb phenol and 2-methoxyphenol on \\
\hline $\begin{array}{l}\text { Keywords: } \\
\text { zeolite, } \\
\text { dealumination, } \\
\text { adsorption, ab } \\
\text { initio, computing }\end{array}$ & $\begin{array}{l}\text { rice hull liquid smoke have been done. This research was conducted through two } \\
\text { approaches of experiments and ab initio computation. Zeolite dealumination did by } \\
\text { acidification using } \mathrm{HCl} \text { and } \mathrm{H}_{2} \mathrm{SO}_{4} \text {. Natural zeolite before and after dealumination was } \\
\text { analyzed by Atomic Absorption Spectroscopy (AAS). Liquid smoke before and after } \\
\text { adsorption was analyzed by GC-MS. Modelling was carried out at } \mathrm{HF} / 6-31 \mathrm{G} * * \text { level of } \\
\text { theory obtained the lowest interaction energy between dimer tetrahedral segments of } \\
\text { zeolite ratio } \mathrm{Si}-\mathrm{Al} 2-0 \text { with phenol with amount }-19.3313 \mathrm{kkal} / \mathrm{mol} \text { and with } 2- \\
\text { metoksifenol with amount }-22.1246 \mathrm{kkal} / \mathrm{mol} \text {. Natural zeolite dealumination using } 6 \mathrm{~N} \\
\text { hydrochloric acid obtained highest ratio } \mathrm{Si} / \mathrm{Al} \text { with amount } 19,2432 \text {. The result of liquid } \\
\text { smoke adsorption obtained phenol and } 2-\text { metoxyphenol content with amount of } 0,52 \% \\
\text { and } 28,4 \% \text {. From this result concluded that higher ratio } \mathrm{Si} / \mathrm{Al} \text { was able to improve } \\
\text { adsorption phenol and 2-methoxyphenol on rice hull liquid smoke, result of ab initio } \\
\text { computational also proved that dimer tetrahedral segmen of zeolite with highest ratio } \\
\mathrm{Si}-\mathrm{Al} \text { had lowest interaction energy when it interacted with phenol and 2- } \\
\text { methoxyphenol. }\end{array}$ \\
\hline
\end{tabular}

Abstrak

Kata kunci: zeolit, dealuminasi, adsorpsi, $a b$ initio, komputasi
Telah dilakukan penelitian tentang studi kemampuan adsorpsi zeolit alam terdealuminasi terhadap senyawa fenol dan 2-metoksifenol pada asap cair sekam padi. Penelitian ini dilakukan melalui dua pendekatan yaitu eksperimen dan komputasi $a b$ initio. Dealuminasi zeolit dilakukan dengan pengasaman menggunakan asam $\mathrm{HCl}$ dan $\mathrm{H}_{2} \mathrm{SO}_{4}$. Zeolit alam sebelum dan sesudah didealuminasi dianalisis menggunakan Spektroskopi Serapan Atom (SSA). Asap cair sebelum dan sesudah adsorpsi dianalisis menggunakan GC-MS. Pemodelan dilakukan pada tingkat teori HF/6-31G** diperoleh energi interaksi terendah antara segmen dimer tetrahedral zeolit rasio $\mathrm{Si}-\mathrm{Al}$ 2-o dengan fenol sebesar -19,3313 kkal/mol dan dengan 2-metoksifenol sebesar -22,1246 kkal/mol. Dealuminasi zeolit alam menggunakan asam $\mathrm{HCl} 6 \mathrm{~N}$ diperoleh rasio Si/Al tertinggi sebesar 19,2432. Hasil adsorpsi asap cair diperoleh kadar fenol dan 2-metoksifenol terendah ketika diadsorpsi menggunakan zeolit alam dengan rasio Si/Al tertinggi dengan kadar masing-masing 0,52\% dan 28,4\%. Dari data tersebut dapat disimpulkan bahwa semakin tinggi rasio $\mathrm{Si} / \mathrm{Al}$ mampu meningkatkan kemampuan adsorpsi senyawa fenol dan 2-metoksifenol pada asap cair sekam padi, melalui hasil pemodelan juga dibuktikan bahwa segmen tetrahedral zeolit rasio $\mathrm{Si}$-Al tertinggi memiliki energi interaksi terendah terhadap molekul fenol dan 2-metoksifenol. 


\section{Pendahuluan}

Sebagai negara agraris dan salah satu penghasil padi di dunia, potensi ketersediaan sekam padi di Indonesia sangat besar. Berdasarkan data Biro Pusat Statistik (BPS) 2008, pada 2005 produksi padi di Indonesia diperkirakan mencapai 60 juta ton. Artinya, berdasarkan asumsi berat sekam padi dari total berat gabah kering giling yang diproduksi rata-rata 20 persen, maka limbah sekam padi yang dapat dihasilkan kurang lebih sebesar 12 juta ton per tahun. Namun, sekam padi merupakan salah satu biomassa yang selama ini dianggap sebagai limbah setelah proses pengolahan padi.

Asap cair merupakan hasil reaksi degredasi termal dari selulosa, hemiselulosa dan lignin pada proses pirolisis yang dikondensasikan. Asap cair memberikan rasa, warna, tekstur dan pada kasus-kasus tertentu juga digunakan sebagai pengawet pada makanan. Asap cair mempunyai kemampuan untuk mengawetkan karena mempunyai kadar asam, fenol, dan alkohol. Pemanfaatan asap cair lebih lanjut dapat sebagai antioksidan, antibakteri, antimikrobia, dan lain-lain.

Hasil degredasi selulosa, hemiselulosa dan lignin yang terdapat pada sekam padi menghasilkan komponen senyawa volatil mayoritas berupa turunan senyawa-senyawa asam dan fenol [1]. Senyawa turunan fenol yang banyak terdapat dalam asap cair merupakan fenol, 2-metoksifenol, 2,6-dimetoksifenol dan ester fenol termasuk senyawa turunan lainnya dengan cabang-cabang yang memungkinkan antara lain metil, etil, propil, vinil, alil dan rantai samping propenil.

Sangat perlu mengetahui fenomena pada tingkat molekular pengaruh perubahan rasio $\mathrm{Si} / \mathrm{Al}$ dengan cara di dealuminasi terhadap kemampuan adsorbsi zeolit terhadap senyawa fenolat yang terdapat pada asap cair sekam padi . Karena sulitnya untuk mengetahui fenomena pada struktur kompleks framework zeolit sebagai adsorben dengan senyawa adsorbat sehingga dilakukanlah pemodelan segmen dimer struktur tetrahedral (2T) zeolit mewakili struktur kompleks framework zeolit untuk diketahui feomena tingkat molekular yang terjadi antara zeolit dengan senyawa adsorbat [2-6]. Pada penelitian sebelumnya perubahan energi yang diperoleh segmen $2 \mathrm{~T}$ dan $38 \mathrm{~T}$ kluster zeolit tidak berbeda signifikan [7], sehingga pada penelitian ini hanya dilakukan interaksi pada kluster 2T. Dalam penelitian ini senyawa adsorbat yang menjadi tinjauan adalah senyawa fenol dan 2-metoksifenol.

\section{Metodologi}

\section{Alat \& Bahan}

Seperangkat alat pirolisis berkondensor, seperangkat alat destilasi, peralatan gelas, lumpang porselain, saringan ukuran 100 mesh, timbangan listrik, stirrer yang dilengkapi dengan pengatur temperatur, oven, Spektroskopi Serapan Atom (SSA), GC-MS dan seperangkat komputer dengan sistem operasi Windows $X P S P 2$. Program komputasi yang digunakan adalah Gaussiano3 dan untuk menampilkan struktur tiga dimensi digunakan program Molden dan Gaussview. Limbah sekam padi, Akuades, Zeolit alam Bayat, $\mathrm{H}_{2} \mathrm{SO}_{4}$ $3 \mathrm{~N}$ dan $6 \mathrm{~N}, \mathrm{HCl} 3 \mathrm{~N}$ dan $6 \mathrm{~N}$ dan $\mathrm{NH}_{4} \mathrm{Cl} 0,1 \mathrm{~N}$.

\section{Prosedur penelitian}

Perhitungan interaksi antarmolekul antara zeolit sebagai adsorben dengan fenol dan 2-metoksifenol sebagai adsorbat dilakukan menggunakan metode perhitungan mekanika kuantum ab initio pada tingkat teori dan basis set $\mathrm{HF} / 6-31 \mathrm{G}^{* *}$. Tahap pertama yaitu optimasi geomerti nolekul tunggal. Geometri optimasi molekul tunggal selanjutnya digunakan untuk perhitungan optimasi geomerti asosiasi molekul berpasangan (interaksi antarmolekul). Selanjutnya perhitungan $a b$ initio molekul berpasangan dilakukan terhadap,

2T-ZH/Ro-2...fenol dan 2T-ZH/Ro-2...2-metoksifenol

2T-ZH/R1-1...fenol dan 2T-ZH/R1-1...2-metoksifenol

2T-ZH/R2-0...fenol dan 2T-ZH/R2-0...2-metoksifenol

dengan variasi jarak $(R)$. Untuk setiap interaksi molekul berpasangan masing-masing dapat dituliskan sebagai berikut:

$$
\begin{aligned}
& \Delta E_{\text {dimer zeolit...66H60 }}(\mathrm{R})=E_{\text {dimer zeolit... } 6 \text { 6 } 6 \mathrm{H} 60}-\left(E_{\text {dimer zeolit }}+E\right. \\
& \text { С6H60) }
\end{aligned}
$$

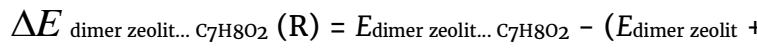

$$
\begin{aligned}
& \left.E_{\mathrm{C} 7 \mathrm{H} 802}\right)
\end{aligned}
$$

Energi interaksi yang didapat digunakan untuk membuat kurva energi potensial interaksi antarmolekul dengan hubungan antara $\Delta E_{A \ldots B}(R)$ dengan $R$.

\section{Pirolisis Sekam Padi}

Pirolisis sekam padi dilakukan sebanyak $5 \mathrm{~kg}$ sekam padi yang telah dikeringkan dimasukkan ke dalam reaktor pirolisis dan proses dilakukan selama 2 jam pada temperatur $400{ }^{\circ} \mathrm{C}$. Hasil pirolisis yang berupa cairan kemudian dipisahkan dari kandungan tarnya melalui proses distilasi vakum.

\section{Preparasi Zeolit Alam}

Zeolit alam yang akan digunakan dalam penelitian ini berasal dari Bayat. Zeolit digerus sampai halus dan diayak dengan ukuran 100 mesh. Zeolit alam yang telah di gerus di cuci dengan akuades. Selanjutnya dipanaskan dalam oven pada temperatur $110^{\circ} \mathrm{C}$ selama 5 jam. Selanjutnya zeolit dilakukan perendaman dalam larutan asam flourida sambil dilakukan pengadukan dengan magnetic stirrer pada suhu ruangan selama 1 jam.

\section{Dealuminasi Zeolit Alam}

Zeolit alam hasil preparasi diberi perlakuan dealuminasi melalui pengasaman. Metode pengasaman dilakukan menggunakan variasi jenis asam $\mathrm{HCl}$ dan $\mathrm{H}_{2} \mathrm{SO}_{4}$ dengan variasi konsentrasi masing-masing jenis asam $3 \mathrm{~N}$ dan $6 \mathrm{~N}$. Proses dealuminasi dilakukan dengan merendam zeolit ke dalam asam pada suhu ruangan selama 1 jam, di stirrer dan di diamkan kembali. Penyaringan dengan kertas saring halus dan di cuci dengan akuades hingga $\mathrm{pH}$ mendekati netral. Selanjutnya zeolit dikeringkan pada suhu $120^{\circ} \mathrm{C}$ selama 
3 jam dan di masukkan dalan eksikator hingga dingin. Sampel zeolit yang sudah kering direndam dalam larutan ammonium klorida $0,5 \mathrm{~N}$, dishaker selama 3 jam dan didiamkan selama semalam, lalu disaring dengan kertas saring halus serta dicuci menggunakan akuades hingga $\mathrm{pH}$ filtrat mendekati netral. Zeolit dikeringkan dalam oven pada suhu $120^{\circ} \mathrm{C}$ selama 3 jam dan dimasukkan damal eksikator hingga kering dan dingin. Zeolit yang sudah kering dikalsinasi pada suhu $400^{\circ} \mathrm{C}$ selama 4 jam dan didinginkan dalam eksikator.

\section{Adsorbsi Redestilat Asap Cair}

Redestilat asap cair sekam padi dilewatkan melalui adsorben zeolit dalam kolom. Adsorben dimasukkan ke dalam kolom sebanyak 5 gram lalu asap cair sebanyak 15 $\mathrm{mL}$ dituangkan kedalam kolom dan asap cair hasil adsorbsi di tamping dalam botol vial.

\section{Hasil dan Pembahasan}

\section{Dealuminasi Zeolit Alam}

Zeolit alam berasal dari Bayat sebelum mengalami dealuminasi memiliki rasio $\mathrm{Si} / \mathrm{Al}$ sangat rendah sebesar 6,5770 . Untuk meningkatkan kemampuan adsorpsinya zeolit alam diaktivasi melalui proses dealuminasi dengan pengasaman. Pada tabel I ditunjukkan rasio zeolit alam setelah mengalami dealuminasi dengan variasi konsentrasi dan jenis asam. Rasio Si/Al tertinggi diperoleh ketika zeolit alam di dealuminasi menggunakan asam $\mathrm{HCl}$ dengan konsentrasi $6 \mathrm{~N}$ sebesar 19,2432. Hasil pengasaman menggunakan asam $\mathrm{H}_{2} \mathrm{SO}_{4}$ dengan konsentrasi yang sama diperoleh rasio $\mathrm{Si} / \mathrm{Al}$ yang yang lebih rendah sebesar dibandingkan dengan menggunakan asam $\mathrm{HCl}$ sebesar 14,3304. Kemampuan ionisasi asam bervalensi dua lebih rendah dibandingkan dengan asam bervalensi tunggal, sehingga asam bervalensi dua memiliki kekuatan asam yang lebih rendah [8].

Tabel 1: Tabel Rasio Si/Al Zeolit Alam

\begin{tabular}{cccc}
\hline $\begin{array}{c}\text { Kode } \\
\text { Sampel }\end{array}$ & Jenis Asam & Konsentrasi & Rasio Si/Al \\
\hline ZA & - & - & 6,5770 \\
ZAH-1a & $\mathrm{HCl}$ & $6 \mathrm{~N}$ & 19,2432 \\
ZAH-1b & $\mathrm{HCl}$ & $3 \mathrm{~N}$ & 14,0071 \\
ZAH-2a & $\mathrm{H}_{2} \mathrm{SO}_{4}$ & $6 \mathrm{~N}$ & 14,3304 \\
ZAH-2b & $\mathrm{H}_{2} \mathrm{SO}_{4}$ & $3 \mathrm{~N}$ & 11,5277 \\
\hline
\end{tabular}

Interaksi asam dengan permukaan zeolit mengakibatkan keluarnya spesies alumina dari zeolit. Ion $\mathrm{H}^{+}$yang berasal dari asam mempengaruhi elektron bebas pada atom $\mathrm{O}$ untuk membentuk ikatan koordinasi. Dengan demikian pada Al-O akan kekurangan elektron sehingga akan bersifat lebih polar dan tidak sekuat sebelumnya, sehingga Al akan putus dari ikatannya. Reaksi yang dimungkinkan terjadi ditunjukkan pada gambar 1.

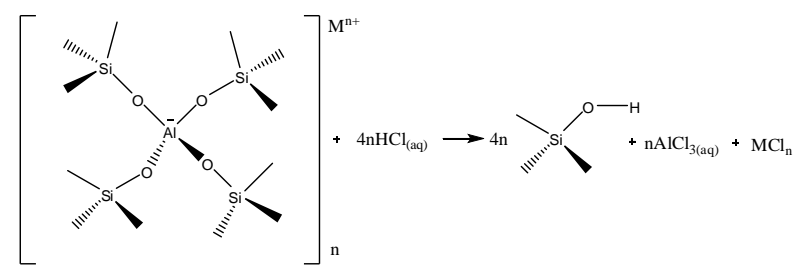

Gambar 1. Perkiraan Mekanisme Reaksi Dealuminasi Zeolit

\section{Adsorpsi Asap Cair}

Asap cair hasil pirolisis di destilasi untuk menghilangkan kandungan tar yang masih terkandung di dalamnya. Asap cair sebelum di adsorpsi memiliki kandungan fenol sebesar $12,88 \%$ dan 2-metoksifenol $39,93 \%$. Untuk menurunkan kandungan fenol yang berifat karsinogenik dilakukan dengan metode adsorpsi menggunakan kolom [9]. Pada tabel 2 ditunjukkan kandungan fenol dan 2-metoksifenol asap cair hasil adsoprsi menggunakan zeolit alam dengan variasi rasio $\mathrm{Si} / \mathrm{Al}$ yang diperoleh dari hasil dealuminasi.

Tabel 2. Hasil Analisis GC-MS senyawa Fenol dan 2metoksifenol pada asap cair dengan variasi rasio $\mathrm{Si} / \mathrm{Al}$ adsorben zeolit alam

\begin{tabular}{ccccc}
\hline $\begin{array}{c}\text { Kode } \\
\text { Sampel }\end{array}$ & Adsorben & $\begin{array}{c}\text { Rasio Si/Al } \\
\text { Adsorben }\end{array}$ & Fenol & $\begin{array}{c}2- \\
\text { metoksifenol }\end{array}$ \\
\hline AC-1a & ZAH-1a & 19.2432 & 0,52 & 28,4 \\
AC-1b & ZAH-1b & 14.0071 & 4,93 & 31,84 \\
AC-2a & ZAH-2a & 14.3304 & 4,28 & 31,46 \\
AC-2b & ZAH-2b & 11.5277 & 6,78 & 33,47 \\
AC-0 & ZA & 6.5770 & 9,58 & 35,3 \\
\hline
\end{tabular}

Hasil analisis GC-MS asap cari hasil pirolisis di peroleh 41 peak pada grafik kromatogram. Kromatogram dapat dilihat pada gambar 2 .

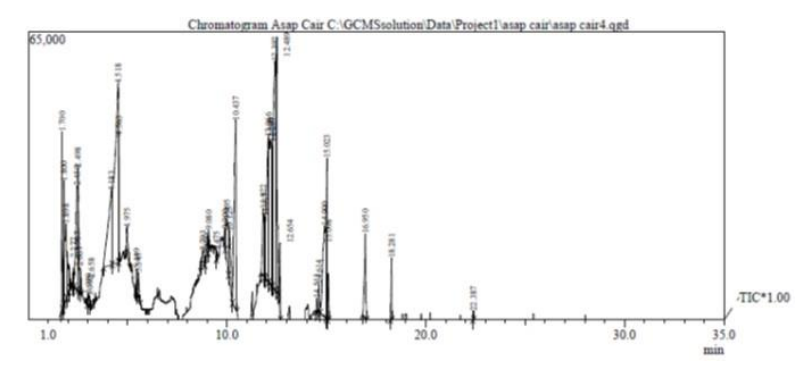

Gambar 2. Kromatogram asap cair sebelum adsorpsi (AC-S)

Analisis asap cair hasil pirolisis sebelum di adsorpsi (AC-S) diperoleh kandungan fenol sebesar 12,88\% ditunjukkan pada peak ke-25 pada waktu retensi 10,437 menit. Kandungan senyawa 2-metoksifenol ditunjukkan pada peak ke-29 pada waktu retensi 12,2 menit. Asap cair AC-o diadsorpsi dengan zeolit alam sebelum di dealuminasi, diperoleh hasil kandungan fenol pada peak ke-21 sebesar 9,58\% pada waktu retensi 10,121 menit. Senyawa 2-metoksifenol pada asap cair AC-o diperoleh sebesar 35,3\% pada peak ke-27. Hasil ini menunjukkan bahwa zeolit memiliki kemampuan untuk 
mengadsorpsi senyawa-senyawa aromatik kususnya fenol dan 2-metoksifenol.

Asap cair AC-2b, AC-1b dan AC-2a masing-masing di adsorpsi menggunakan zeolit terdealuminasi dengan hasil rasio Si/Al sebesar 11,5277; 14.0071 dan 14.3304. Hasil analisis GC-MS menunjukkan penurunan kandungan senyawa fenol semakin besar pada penggunaan adsorben dengan rasio $\mathrm{Si} / \mathrm{Al}$ semakin tinggi. Kandungan senyawa fenol asap cair AC-2b, AC$1 \mathrm{~b}$, dan AC-2a masing-masing sebesar 6,78\%, 6,45\% dan 4,93\%, sedangkan kandungan senyawa 2metokifenol nya sebesar $33,47 \%, 31,84 \%$ dan $31,46 \%$.

Keluarnya alumunium dari kerangka zeolit menyebabkan permukaan zeolit alam menjadi bersifat lebih non polar daripada sebelumnya, sehingga kemampuan adsoprsi zeolit alam terhadap fenol yang cenderung bersifat non polar meningkat.

Kemampuan adsorpsi terbaik terjadi pada zeolit ZAH-1a dengan rasio Si/Al tertinggi sebesar 19,2432 yang digunakan untuk mengadsorpsi asap cair $\mathrm{AC}-1 \mathrm{a}$ menghasilkan kandungan fenol sebesar $0,52 \%$ dan 2metoksifenol sebesar 28,4\%. Kromatogran asap cair AC1a dapat dilihat pada gambar 3 .

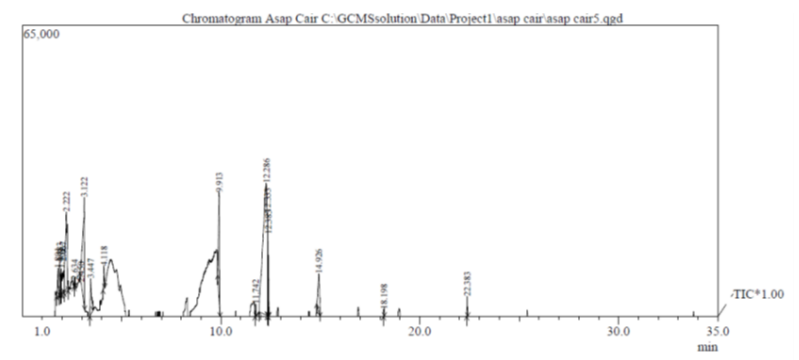

Gambar 3. Kromatogram asap cair setelah di adsorpsi dengan zeolit $\mathrm{ZAH}-1 \mathrm{a}(\mathrm{AC}-1 \mathrm{a})$

Dari Kromatogram asap cair AC-1a pada gambar 3 juga menunjukkan bahwa pada asap cair AC-1a lebih banyak senyawa yang teradsorpsi, hal ini dapat dilihat dengan melihat jumlah peak pada grafik kromatogram asap cair AC-S pada gambar II terdapat 41 peak sedangkan pada hasil kromatogram asap cair AC-1a gambar 3 menunjukkan hanya terdapat 18 peak.

Dari hasil penelitian ini menunjukkan bahwa kemampuan adsorpsi tertinggi pada zeolit ZAH-1a dengan rasio $\mathrm{Si} / \mathrm{Al}$ sebesar 19.2432 yaitu dengan hasil asap cair AC-1a sebasar senyawa fenol $0,52 \%$ dan senyawa 2-metoksifenol $28,4 \%$. Hal ini sesuai dengan penelitian sebelumnya yang pernah dilakukan, permukaan zeolit akan semakin bersifat hidrofobik jika rasio Si/Al meningkat sehingga kemampuan adsorpsi zeolit terhadap senyawa-senyawa non polar semakin meningkat.

Fenomena molekular pengaruh zeolit alam terdealuminasi menjadi penting untuk mengetahui nilai kuantitatif yang terjadi pada tingkat molekular dengan melihat pengaruh perubahan rasio Si/Al terhadap energi interaksi yang terjadi terhadap adsorbat. Kimia komputasi memungkinkan penentuan struktur/ geometri dan energi interaksi berbagai molekul secara teliti. Perhitungan dilakukan dengan metode ab initio pada tingkat teori HF dengan basis set $6-31 \mathrm{G}^{* *}$ menggunakan program Gaussian03, dengan mengasumsikan molekul pada fasa gas. Informasi yang bisa didapat dari hasil perhitungan antara lain energi molekul, muatan masing-masing atom, muatan total, momen dipol, frekuensi vibrasi molekul dan lain-lain [10-12].

Zeolit terdiri dari monomer-monomer tetrahedral $\left(\mathrm{SiO}_{4}\right)_{4}^{-}$dan $\left(\mathrm{AlO}_{4}\right)_{5}{ }^{-}$. Pemodelan struktur dimer zeolit dilakukan dengan memunculkan adanya situs asam Brownsted di dalamnya, karena transfer proton dari situs asam Brownsted merupakan tahapan penting pada proses adsorbsi [7]. Tahap awal dari studi komputasi perhitungan ab initio adalah optimasi geometri molekul tunggal antara lain senyawa fenol, 2-metoksifenol dan segmen dimer zeolit dengan variasi Rasio Si/Al 2-0, 1-1 dan 0-2. Hasil optimasi molekul tunggal diperoleh geometri dan beberapa parameter yang ditunjukkan pada tabel 3.

Optimasi geometri bertujuan untuk mendapatkan struktur molekul tiga dimensi dengan energi minimum global (keadaan paling stabil). Penentuan optimasi geometri molekul diawali dengan perkiraan awal struktur yang dinyatakan dalam matrik-Z.

Tabel 3. Tabel struktur geometri dan beebrapa parameter hasil optimasi molekul tunggal

\begin{tabular}{|c|c|c|c|}
\hline No & Struktur & $\begin{array}{c}\text { Energi } \\
\left(10^{3} \mathrm{kkal} / \mathrm{mol}\right)\end{array}$ & $\begin{array}{l}\text { Momen Dipol } \\
\text { (Debye) }\end{array}$ \\
\hline 1 & & $-635,318$ & 1,9593 \\
\hline
\end{tabular}

$2 \mathrm{~T}-\mathrm{ZH} / \mathrm{R} 0-2$

2

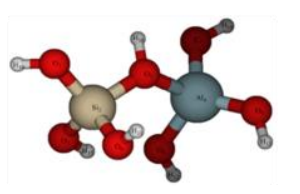

$-664,771$

1,6794

2T-ZH/R1-1

3

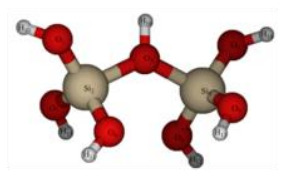

$--694,118$

1,4005

2T-ZH/R2-0

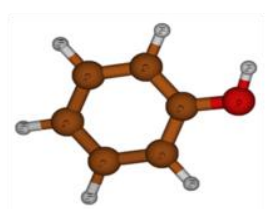

$-191,751$

1,4286

5

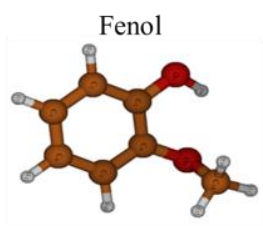

$-263,213$

2,1449

2-metoksifenol 
Tahap selanjutnya adalah penentuan geometri asosiasi molekul berpasangan antara lain fenol dan 2metoksifenol yang berinteraksi dengan segmen dimer zeolit pada setiap variasi rasio $\mathrm{Si} / \mathrm{Al}$, beserta penentuan energi interaksinya.

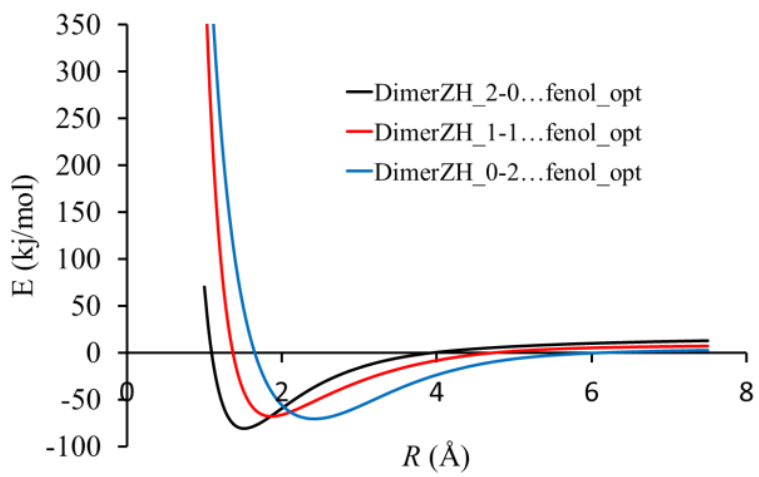

Gambar 4. Grafik potensial interaksi $\Delta E(\mathrm{~kJ} / \mathrm{mol})$ terhadap $R(\AA)$ pada 2T-ZH...fenol.

Setelah mendapatkan konfigurasi asosiasi molekul berpasangan, dilakukan perhitungan energi sebagai fungsi jarak. Sehingga dapat mengetahui jarak dan energi interaksi van der Waals yang paling stabil dalam molekul berpasangan tersebut. Variasi jarak dibuat antara 1,5 $\AA$ sampai 7,5 $\AA$, di mana pada jarak yang jauh tidak ada interaksi dan pada jarak sangat dekat terjadi tolak-menolak antar inti. Interaksi antara atom dan molekul dapat dihitung menggunakan mekanika kuantum dengan teliti, dan dapat ditunjukkan dengan model kurva potensial interaksi. Energi interaksi segmen tetrahedral zeolit dengan variasi rasio $\mathrm{Si}-\mathrm{Al}$ terhadap molekul fenol dan 2-metoksifenol sebagai fungsi jarak ditampilkan dalam grafik $E(R)$ dengan $R$ (gambar 4 dan 5).

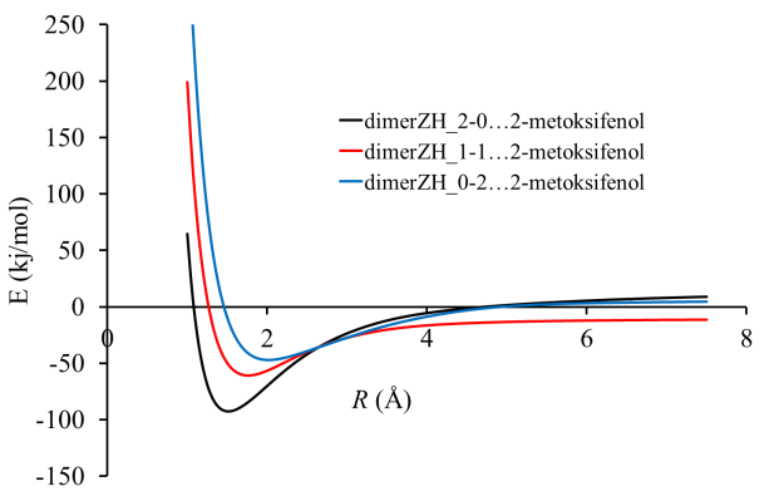

Gambar 5. Grafik potensial interaksi $\Delta E(\mathrm{~kJ} / \mathrm{mol})$ terhadap $R(\AA)$ pada 2T-ZH...2-metoksifenol.

Hasil perhitungan energi interaksi adsorben dengan adsorbat melalui perhitungan komputasi $a b$ initio dapat diringkas pada tabel 4. Dari tabel 4 memberikan informasi bahwa menurut hasil perhitungan $a b$ initio terjadi interaksi antara adsorben dimer zeolit dengan adsorbat fenol dan 2-metoksifenol. Hasil perhitungan tersebut mendukung hasil eksperimen yang juga dilakukan pada penelitian ini.
Tabel 4. Tabel asosiasi molekul berpasangan dan parameter interaksi

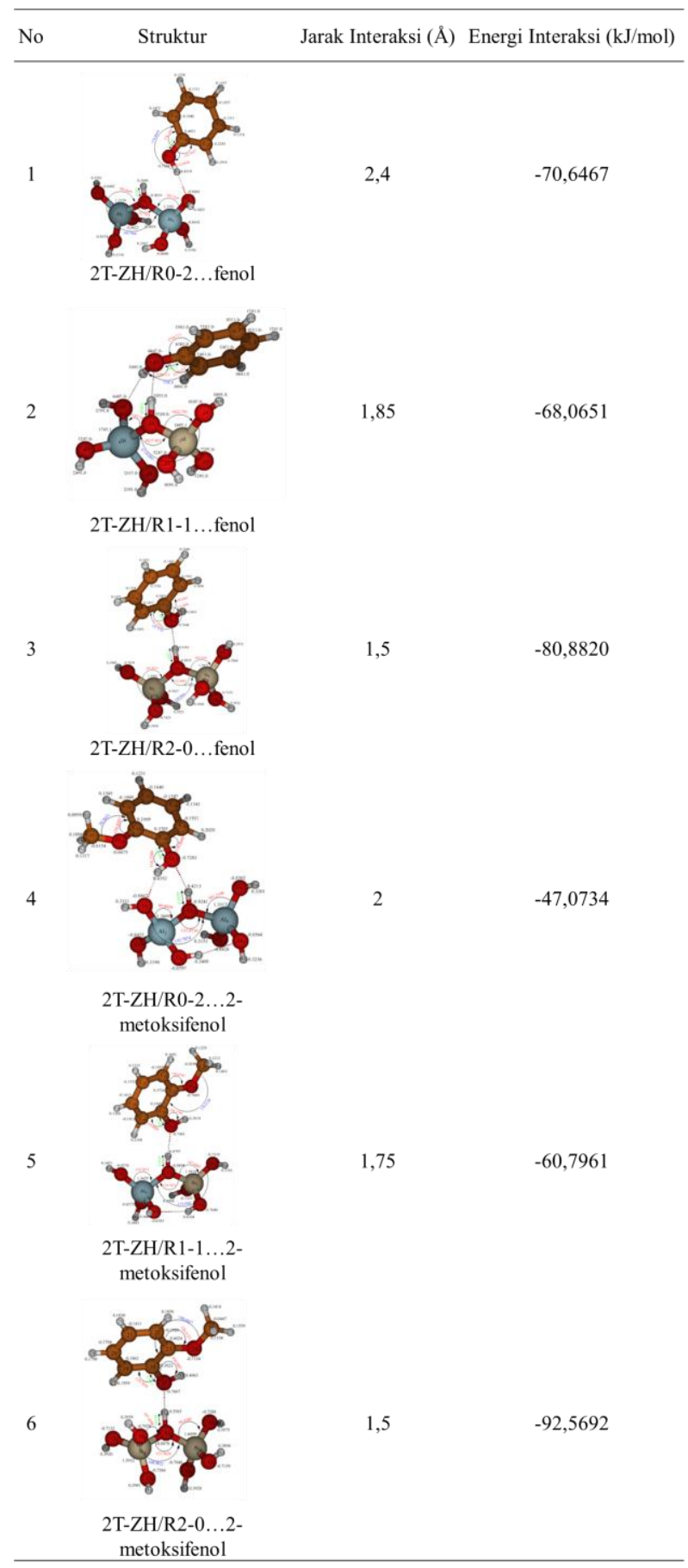

Energi interaksi 2T-ZH/R2-0, 2T-ZH/R1-1 dan 2T$\mathrm{ZH} / \mathrm{Ro}-2 \mathrm{Si} / \mathrm{Al}$ dengan fenol dan 2-metoksifenol umum menunjukkan peningkatan energi interaksi dengan semakin tingginya rasio $\mathrm{Si} / \mathrm{Al}$. Namun terdapat penyimpangan pada hasil energi interaksi 2T-ZH/R11...fenol karena energi interaksi yang diperoleh lebih kecil dibandingkan dengan 2T-ZH/Ro-2...fenol yang memilik rasio Si/Al lebih rendah. Pada interaksi dimer zeolit terhadap fenol diperoleh energi tertinggi pada 2TZH/R2-0...fenol hal ini menunjukkan bahwa semakin tinggi rasio Si/Al semakin kuat energi interaksi yang terjadi, hasil tersebut juga ditunjukkan pada interaksi dimer zeolit terhadap 2-metoksifenol energi terbesar diperoleh pada 2T-ZH/R2-0..2-metoksifenol. Dengan 
demikian meningkatkan rasio $\mathrm{Si} / \mathrm{Al}$ pada zeolit alam dapat meningkatkan kemampuan adsorpsi. Dari penelitian ini, hasil perhitungan ab initio pada tingkat teori dan basis set $\mathrm{HF} / 6-31 \mathrm{G} * *$ dapat memberikan perkiraan dan informasi interaksi yang terjadi dalam proses adsorpsi molekul fenol dan 2-metoksifenol yang terdapat pada asap cair menggunakan zeolit alam terdealuminasi, sehingga eksperimen dan teori saling melengkapi.

\section{Kesimpulan}

Dealuminasi zeolit alam dapat dilakukan dengan pengasaman menggunakan asam kuat. Asam $\mathrm{HCl}$ memiliki kemampuan lebih baik untuk mendealuminasi zeolit alam. Dealuminasi zeolit alam dapat meningkatkan kemampuan adsorpsi zeolit alam terhadap senyawa fenol dan 2-metoksifenol pada asap cair sekam padi. Hasil Eksperimen sesuai dengan teori hasil perhitungan komputasi ab initio bahwa semakin tinggi rasio $\mathrm{Si} / \mathrm{Al}$ semakin kuat interaksi yang terjadi antara zeolit alam dengan senyawa fenol dan 2metoksifenol.

\section{Daftar Pustaka}

[1] Wen-Chieh Sung, Martha Stone, Fang-Ming Sun, Analysis of Volatile Constituents of Different Temperature Rice Hulls Liquid Smoke, Chia-Nan Annual Bulletin, 33, (2007) 1-12

[2] Parsaoran Siahaan, Cynthia L Radiman, Susanto Imam Rahayu, Muhamad A Martoprawiro, Dieter Ziessow, Molecular Interaction Between Benzonitrile and Hexamethylphosphoric Triamide by $13 \mathrm{C}$ NMR $\mathrm{T} 1$ Relaxation Time Studies and $\mathrm{AB}$ Initio QM Calculations: Extended Investigation, Indonesian Journal of Chemistry, 9, 2, (2010) 292-296 http://dx.doi.org/10.22146/ijc.523

[3] Muflikhah, Perhitungan AB Initio Interaksi Antara Trikalsium Fosfat Dan Hidroksiapatit Dengan Segmen Molekul Selulosa, Kimia, Universitas Diponegoro, Semarang

[4] Lorene Abella, Keiichiro Yamamoto, Kenji Fukuda, Shinkoh Nanbu, Noriko Oikawa, Koji Morita, Tatsuya Matsumoto, Ab initio calculations for the reaction paths of levoglucosan: An intermediate of cellulose pyrolysis, Memoirs of the Faculty of Engineering, Kyushu University, 66, 2, (2006) 147-168

[5] K Doll, JC Schön, M Jansen, Structure prediction based on ab initio simulated annealing, Journal of Physics: Conference Series, (2008).

[6] J. Limtrakul, S. Nokbin, P. Chuichay, P. Khongpracha, S. Jungsuttiwong, T. N. Truong, 15O-04 - Coverage effects on adsorption of water in faujasite: an ab-initio cluster and embedded cluster study, Studies in Surface Science and Catalysis, 135, (2001) $\quad 149 \quad$ http://doi.org/10.1016/S01672991(01)81242-8

[7] Larry A. Curtiss, Stanislaus A. Zygmunt, Lennox E. Iton, $\mathrm{Ab}$ initio and density functional studies of hydrocarbon adsorption in zeolites, 12th International Zeolite Conference, Baltimore, Maryland, (1998).
[8] Douglas A Skoog, F James Holler, Stanley R Crouch, Principles of instrumental analysis, Cengage learning, 1994.

[9] Hardjono Sastrohamidjojo, Kimia Minyak Atsiri, Gadjah Mada University Press, Yogyakarta, 2004.

[10] A. White, F. J. Zerilli, H. D. Jones, Ab initio calculation of intermolecular potential parameters for gaseous decomposition products of energetic materials, in, DSTO Aeronautical and Maritime Research Laboratory, Melbourne, Victoria, Australia, 2000.

[11] IE Boldeskul, LF Sukhodub, AN Kalinkevich, VD Khavryutchenko, Ab initio modelling of calcium phosphate clusters and their vibrational spectra, Condensed Matter Physics, 9, 4, (2006) 669-679

[12] J Foresman, E Frish, Exploring chemistry, Gaussian Inc., Pittsburg, USA, (1996) 